Uşak Üniversitesi Sosyal Bilimler Dergisi

$2016,9 / 1$

\title{
Bir Dersin Harmanlanmış Öğrenme Yöntemiyle İşlenmesinin Öğrencilerin Akademik Güdülenmelerine Etkisi*
}

Fatih BALAMAN**

\section{Öz}

Çalışmada Harmanlanmış Öğrenme ortamının öğrencilerin akademik güdülenmelerine etkisi araştırılmıştır. Bu amaçla çalışma Mustafa Kemal Üniversitesi Kırıkhan Meslek Yüksekokulunda 2014-2015 öğretim yılı bahar yarıyılında Veritabanı Yönetim Sistemleri dersini alan 42 öğrenci ile gerçekleştirilmiştir. Ön test - son test yarı deneysel olarak tasarlanan çalışmada öğrencilerin akademik güdülenme düzeylerini ölçmek amacıyla Bozanoğlu (2004) tarafından geliştirilen Akademik Güdülenme Ölçeği kullanılmıştır. 5 hafta süren çalışma boyunca deney grubuna Harmanlanmış Öğrenme ile kontrol grubuna ise Geleneksel Öğrenme ile öğretim yapılmıştır. Veriler analiz edilirken ilk olarak grupların ön testleri daha sonra son testleri karşılaştırılmış, bu amaçla veriler arasında Bağımsız Gruplar t Testi yapılmıştır. Daha sonra her bir grubun çalışma boyunca akademik güdülenme bakımından ilerlemeleri incelenmiştir. Bu nedenle her bir grubun ön testleri ile son testleri karşılaştırılarak, grup içinde İlişkili Örneklemler t Testi yapılmıştır. Çalışma sonunda gerçekleştirilen analizler sonucunda Harmanlanmış Öğrenmenin ve Geleneksel Öğrenmenin öğrencilerin akademik güdülenmelerini arttırmada etkisi olduğu fakat Harmanlanmış Öğrenmenin öğrencilerin akademik güdülenmelerini arttırmada Geleneksel Öğrenmeye göre üstünlüğü olmadığı sonucuna ulaşılmıştır.

Anahtar Kelimeler: Harmanlanmış Öğrenme, Güdülenme, Web, Uzaktan Eğitim

\footnotetext{
* Makalenin özeti 16-18 Nisan 2015 tarihleri arasında Niğde'de düzenlenen 24.Ulusal Eğitim Bilimleri Kongresinde sözlü bildiri olarak sunulmuştur.

** Öğr. Gör. Dr., Mustafa Kemal Üniversitesi, Kırıkhan Meslek Yüksekokulu, Bilgisayar Teknolojileri Bölümü, fatihbalaman2010@gmail.com
} 


\title{
The Effect of Teaching a Course by Using the Method as Blended Learning upon the Academic Motivation Levels of Students
}

\begin{abstract}
In this study, the effect of Blended Learning environment on students' motivation level was dealt. Hence, 42 students who took the course as Database Management Systems in the relevant academic semester as 2014-2015 in Mustafa Kemal University Kurıkhan Vocational School participated in our research. This study used the academic motivation scale which was created by Bozanoğlu (2004) in order to measure the academic motivation levels of student being designed as pre-test- end test in a semi experimental form. Throughout the study which were 5 weeks, the Blended Learning method was used for the experiment group, on the other hand the Traditional Learning methods were performed for the control group. As the datum were analyzed, the pre test and end-test results of the groups were compared at first. Independent Groups t-Test was performed for the datum. Afterwards, an analysis for one specific group on behalf of improvement about academic motivation throughout the study was performed. In this respect the pre-test and end results of each group were compared then in group related samples t-test was performed. As a result of the study, owing to the analysis it was concluded that the Blended Learning is not comparatively more superior than the Traditional Learning methods on behalf of improving the academic motivation of students.
\end{abstract}

Keywords: Blended Learning, Motivation, Web, Distance Education

\section{Giriş}

Harmanlanmış Öğrenme geleneksel öğretim ile öğretim amaçlı çevrim içi teknolojilerin bir arada kullanılmasıdır. Bu öğrenme türünde çoğunlukla geleneksel öğrenme ile Web Tabanlı Öğrenme harmanlanarak kullanılmaktadır (Garisson ve Vaughan, 2008; Moore, 2013). Geleneksel Öğrenme ile e-öğrenmenin güçlü yönleri zaman, öğrenci, öğretmen, amaç, materyal gibi değişkenler bakımından bütünleştirilip beraber kullanılarak da Harmanlanmış Öğrenme ortamları oluşturulabilir (Ünsal, 2012; Dağ, 2011). Çardak (2012) ise Harmanlanmış Öğrenme'yi öğrencilere zengin ve etkili bir öğrenme ortamı sunmak için geleneksel öğrenme ortamları ile çevrim içi öğrenme ortamlarının uyumlu şekilde bir arada kullanması, harmanlanması olarak tanımlamaktadır. Harmanlanmış Öğrenme Web Tabanlı Eğitim'de etkileşim problemini en aza indirmek, Geleneksel Eğitim'i web teknolojileri ile desteklemek gayretindedir (Usta ve Mahiroğlu, 2008). Harmanlanmış Öğrenme'de önemli olan e-öğrenme teknolojileri ile 
geleneksel öğretimin belli ölçülerde kullanılması ve bu ölçünün gereksinim doğrultusunda olmasıdır (Dağ, 2011). Her iki öğretimin kullanımında dengenin sağlanması uygulamanın yapıldığı dersin yapısına, öğretimin hedeflerine, öğrenci özelliklerine bağlıdır. Dikkate alınması gereken her iki yöntemin avantajlarından azami ölçüde yararlanmaktır (Uluyol ve Karadeniz, 2009). Bu sayede daha etkin öğrenme ortamlarının oluşması sağlanmaktadır.

Web teknolojilerinin öğretimde kullanılabildiği esnek bir yaklaşım olarak da tanımlanan Harmanlanmış Öğrenme, zaman ve mekân sınırlaması olmadan sanal kaynaklara kolay erişim sayesinde özellikle yükseköğretimde yaygın olarak kullanılmaktadır (Geçer, 2013). Yükseköğretim kurumlarının teknolojideki gelişmelere bağlı olarak artan şekilde harmanlanmış öğrenmeye veya tamamen çevrim içi öğrenmeye yöneldikleri görülmektedir (Al-Ani, 2013; Picciano ve Dziuban, 2007; Oliver ve Trigwell, 2005). Bunun sebepleri arasında yükseköğretimde eğitimin daha esnek olması, bu düzeydeki öğrencilerin teknolojiyi kullanma bilgi ve becerilerinin diğer düzeydeki öğrencilere göre fazla olması, yükseköğretim öğrencilerinin öğrenmeye olan ilgi ve ihtiyaçlarını karşılamada internet ve bilgisayar kullanımının daha uygun olması gibi sebepler sayılabilir.

Ginns ve Ellis (2007)'e göre üniversitelerde öğretim elemanlarının öğretim kalitesi anlayışları, bilgi ve iletişim teknolojilerinin kullanımı ile ilişkilidir. Bu durum teknolojik yeniliklerin eğitimde kullanımının önemini ifade etmektedir. Nitekim güncel bilgi ve iletişim teknolojileri öğretmenlere ve öğrencilere öğretimde büyük kolaylıklar sağlamaktadır (Pérez, López ve Ariza, 2011; Garisson ve Vaughan, 2008). Harmanlanmış Öğrenme'de bu eğitim materyallerinin yoğun olarak kullanıldığı görülmektedir (Bonk ve Graham, 2006). Öğrenme materyallerinin daha fazla kullanıldığı derslerde öğrenme düzeyinde artış olması daha muhtemeldir (Dennis vd., 2006). Harmanlanmış Öğrenme'nin geleneksel olarak gerçekleşen bölümü öğrencilerin ve öğretmenin alışık, deneyim sahibi oldukları kısmıdır. Yöntemi farklı ve etkili kılan ise web teknolojilerinin kullanıldığı kısmıdır. Harmanlanmış Öğrenme'de birden fazla yöntem kullanılarak bu yöntemlerin avantajlarından yararlanılmaya çalışılmaktadır (Çardak, 2013).

Harmanlanmış Öğrenme ortamına maruz kalan öğrencilerin bilgisayar ve internet sahibi olma, belli düzeyde bilgisayar kullanımı ve teknik bilgiye sahip olma zorunlulukları ile web ortamında öğrenme sürecinde disiplin sorunları yaşama ihtimalleri de Harmanlanmış Öğrenme'nin önemli dezavantajları arasındadır (Dikmenli ve Ünaldı, 2013).

Problem temelli öğrenmede yeni medya ve Öğrenme Yönetim Sistemi kullanımı öğrencilerin güdülenme düzeylerini arttırmada etkilidir 
(Schober ve Keller, 2012). Öğrenme Yönetim Sistemleri, eğitim yönetiminin otomasyon üzerinden yapıldığı yazılımlardır (Aktaş, 2013). MOODLE, ATutor gibi hazır Öğretim Yönetim Sistemi yazılımları öğrenci, öğretmen ve yönetici rolündeki bireyler için kullanım kolaylığı sağlamaktadır (Ezginci, 2008). Öğretim Yönetim Sistemi kullanımı öğrenciler tarafından olumlu karşılanmakta ve öğrencilerin derse yönelik güdülenme düzeylerini arttımaktadır (Geçer ve Dağ 2012). Öğretim Yönetim Sistemleri hem öğretmen hem de öğrenci için öğrenme - öğretme sürecini elektronik ortamda yönlendirmede kullanılmakta, öğretmenlerin ders ile ilgili farklı türlerde doküman paylaşımına olanak sağlamakta, öğrencinin de bu dokümanlardan yararlanmalarına imkan tanımaktadır. Bu sistemlerin genelinin kullanımının oldukça basit olması ve kullanıcının kolayca yönlendirilmesini sağlaması iş yükünü azaltmıştır. Öğretim Yönetim Sistemleri'nin bu avantajları kullanıcılar olarak öğrenci ve öğretmende memnuniyete sebep olmaktadır.

Güdüleme, bireyi belirlenen davranışı gerçekleştirmeye karşı daha istekli kılmak için planlanan çalışmalardır (Sönmez, 2010). İnsanın bir davranışı sergilemesi, o davranış ile ilgili güdülenme düzeyine bağlıdır. Güdülenme, herhangi bir davranışı gerçekleştirmedeki amacın ve enerjinin kaynağıdır (Demir, 2008). Güdülenmişlik düzeyi yüksek bireyler, güdülenme ile ilişkili davranışları yerine getirme sürecinde daha başarılıdırlar. Ayrıca bu bireyler derslerde hedeflerine daha iyi odaklanmaktadırlar ve daha az akademik erteleme davranışı sergilemektedirler (Akbay, 2009).

Akademik güdülenme, öğrencilerin derse karşı güdülenme durumlarını ifade etmektedir (Ünal, 2013). Akademik güdü arttıkça akademik başarı da artmaktadır. Akademik güdülenmesi yüksek öğrenciler öğrenme esnasında karşılaştı̆̆ 1 zorluk karşısında öğrenmeden vazgeçmeyi tercih etmezken, güdülenme düzeyi düşük öğrenciler bu durumda öğrenmeden vazgeçmeyi daha çok tercih etmektedirler (Aydın, 2010). Öğrencinin akademik güdülenmesi için, onun ilgisini ve dikkatini çekecek faaliyetlerde bulunulabilir. Bu faaliyetler kullanılacak öğretim yöntemleri ile mümkün olabilir. Harmanlanmış öğrenmede kullanılan web tabanlı öğretim sayesinde teknolojik imkanlar eğitim amaçlı kullanılarak öğrencinin ilgisi çekilir, böylece öğrencinin güdülenmesi sağlanabilir. Yüksek öğretim düzeyindeki bireylerin bilgisayar ve internet teknolojilerine ilgi duydukları ve bu teknolojilerin onlara çekici geldiği bilinmektedir. Bu nedenle harmanlanmış öğrenme ile öğrencilerin ilgi ve dikkatleri ders ile ilgili konulara çekilerek güdülenmeleri sağlanabilir. 
Harmanlanmış Öğrenme'nin amacına ulaşmasında temel gereksinim olan öğrenci memnuniyeti aynı zamanda Harmanlanmış Öğrenme'nin niteliğini etkileyen önemli bir faktördür. Öğrenci memnuniyeti öğrencinin derse güdülenmesini ve başarı düzeyini arttırabilir (Naaj, Nachouki ve Ankit, 2012). Ayrıca Harmanlanmış Öğrenme'nin güncel bir yaklaşım olması ve bu öğrenmede kullanılan web teknolojilerinin ilgi çekici olması da öğrencilerin güdülenmesinde ve başarılarının artmasında rol oynayan faktörler arasındadır (Topal, 2013).

İnternet ortamında birçok ders ile ilgili bilgiler olmasına rağmen internete eklenen bilgilerin doğru veya yanlış olduğu ile ilgili bir süzgeç yoktur. Bu nedenle kullanıcıları yanlış yönlendirebilecek bilgiler de web ortamında yer alabilmektedir. Ayrıca belli bir dersin konularını kapsayacak derecede düzenli olarak hazırlanmayan öğrenme materyalleri tam olarak öğrenme amacını karşılamayabilir.

Veritabanı Yönetim Sistemleri ders içeriğinde birçok kodlama yer almaktadır. Kodlamaların öğrenilmesinde öğrencilerin fazlaca konu ile ilgili uygulama yapmaları gerekmektedir. Dersin bu özelliği dikkate alındığında sadece ders içi öğrenme faaliyetleri yeterli olamamakta, ders dışında da öğrencilerin ders konularını pekiştirici faaliyetlerde bulunmaları gerekmektedir.

Sınıf içerisinde gerçekleşen eğitimi desteklemek, öğrencilerin okul dışında da konu ile ilgili uygulamalar yapabilmesini sağlayarak daha etkin öğrenme ortamları oluşturabilmek için Harmanlanmış Öğrenme ortamı kullanılmıştır. Bu sayede öğrencilerin derse karşı güdülenme düzeyleri arttırılabilir. Nitekim güdülenme, öğrencilerin başarı düzeylerini etkileyen en önemli faktörler arasındadır.

\section{Araştırmanın Amacı}

Çalışmanın genel amacı, bir dersin harmanlanmış öğrenme yöntemi ile işlenmesinin öğrencilerin akademik bakımdan güdülenmelerine etkisinin olup olmadığını, varsa bu etkinin yönünü ve derecesini tespit etmektir. Bu amaçla harmanlanmış öğrenme, geleneksel öğrenme ile karşılaştırılarak öğrencilerin akademik bakımdan güdülenmelerinde iki yöntem arasındaki farklılık ortaya çıkarılmaya çalışılmıştır.

\section{Yöntem}

Bu bölümde Araştırma Modeli, Çalışma Grubu, Veri Toplama Aracı, Deneysel İşlem Süreci ile Verilerin Analizi bölümleri yer almaktadır. 


\section{Araştırma Modeli}

Çalışma ön test - son test kontrol gruplu yarı deneysel desen olarak modellenmiştir. Uygulama öncesinde deney ve kontrol gruplarına "Akademik Güdülenme Ölçeği" uygulanmıştır. Aynı ölçek çalışma sonrasında da gruplara uygulanarak harmanlanmış öğrenme yönteminin öğrencilerin akademik güdülenme düzeylerine etkisi araştırılmıştır. Deneysel çalışmalarda çoğunlukla çalışma grubu üzerinde gerçekleştirilecek işlem bağımsız değişken olarak belirlenir ve bu işlemin bağımlı değişken üzerindeki etkileri incelenir. Yine bu çalışmalarda açıklamalardan ziyade sonuçların nedenleri üzerinde durulur ve tahminlerde bulunulur (Büyüköztürk, Çakmak, Karadeniz, Akgün ve Demirel, 2014). Yarı deneysel olarak gerçekleşen çalışmalar, çalışma grubunu oluşturan bireylerin gruplara rastgele dağılımlarının kontrol edilemediği durumlardır (Çepni, 2012, Karasar, 2007). Çepni (2012)'ye göre merkezi eğitimin uygulandığ1 ve sınıfların araştırmacılar tarafından rastgele atama ile oluşturulmasının mümkün olmadığı eğitim kurumlarında her bir sınıf rastgele yolla deney ve kontrol grubu olarak belirlenmektedir. Grupların belirlenmesinde bireyler değil, sınıflar rastgele atanmaktadır.

\section{Çalışma Grubu}

Çalışma grubu, Mustafa Kemal Üniversitesi Kırıkhan Meslek Yüksekokulunda 2014-2015 öğretim yılı bahar yarıyılında Veri Tabanı Yönetim Sistemleri dersini alan 42 öğrenciden oluşmaktadır. Çalışma grubu ilgili öğretim yılında okulun İnternet ve A $\breve{g}$ Teknolojileri programında öğrenim gören öğrencilerden oluşmaktadır. Deney ve kontrol gruplarından oluşan çalışma grubunda deney grubu 20 öğrenciden, kontrol grubu ise 22 öğrenciden oluşmaktadır. İki şubeden oluşan çalışma grubunda her bir şube rastgele yolla deney ve kontrol grubu olarak belirlenmiştir.

\section{Veri Toplama Aracı}

Öğrencilerin akademik güdülenme düzeylerinin belirlenmesinde Bozanoğlu (2004) tarafından geliştirilen, güvenirlik katsayısı 0.87 olan "Akademik Güdülenme Ölçeği" kullanılmıştır. 5'li Likert tipinde olan ölçek 19 olumlu, 1 olumsuz olmak üzere toplam 20 maddeden oluşmaktadır. Araştırmacı tarafından yüksekokul öğrencileri ile gerçekleştirilen güvenirlik çalışması sonucunda ölçeğin güvenirlik katsayısı Cronbach Alpha değeri 0.815 olarak hesaplanmıştır.

Ölçek Bozanoğlu (2004) tarafından ilk olarak 90 madde olarak hazırlanmış, geçerlik çalışması sonunda 80 maddeye düşürülmüştür. Güvenirlik çalışması kapsamında madde - toplam korelasyonu 0.3'ün 
altında olan 27 madde ile faktör analizi sonucunda 33 maddenin ölçekten çıkarılması ile ölçekteki madde sayısı 20 olarak belirlenmiştir. 20 maddeden oluşan ölçek 3 faktöre ayrılmış ve bu faktörler "Kendini Aşma", "Bilgiyi Kullanma" ve "Keşif" olarak belirlenmiş̧ir.

Ölçekteki tüm maddeler Çalışma Grubu'na uygulanıp SPSS yazılımına puanlama yapılarak girilmiş, olumsuz maddeler için puanlama tersine çevrilmiş ve elde edilen puanlar toplanarak her bir öğrencinin akademik güdülenme puanı elde edilmiştir.

\section{Deneysel İşlem Süreci}

Uygulama 5 hafta boyunca haftada 4 ders saati olmak üzere toplam 20 ders saatini içermektedir. Çalışma boyunca 20 öğrenciden oluşan deney grubuna harmanlanmış eğitim, 22 öğrenciden oluşan kontrol grubuna ise geleneksel eğitim uygulanmıştır.

Deney grubuna harmanlanmış öğrenmeyi gerçekleştirmek üzere Geleneksel Eğitim ve Web Tabanlı Eğitim beraber kullanılmıştır. Kontrol grubu öğrencileri ile dersin işlenmesinde sadece Geleneksel Eğitim kullanılmıştır.

Geleneksel Eğitim her iki grup için de haftada 4 ders saati bilgisayar laboratuarında yüz yüze yapılmıştır. Geleneksel Eğitim gerçekleştirilirken bilgisayar laboratuarında bilgisayar, projeksiyon cihazı, ders kitabı gibi öğretim araç gereçleri kullanılmıştır.

Web Tabanlı Eğitim ise sadece deney grubu öğrencileri ile www.fatihbalaman.com adresine eklenen materyallerin ders dışında öğrenciler tarafından kullanması şeklinde gerçekleşmiştir. İnternet sayfasında araştırmacı tarafından hazırlanan konu anlatım materyali, sesli ve görüntülü eğitim videosu, örnek sorular ve bu soruların cevapları yer almaktadır.

- Konu Anlatım Materyali: Araştırmacı tarafından hazırlanmış olan yazılı metinlerden ve örnek kodlamalardan oluşan kaynaklardır. İnternetteki ve ders kitaplarındaki bilgiler incelenip derlenerek, kısa ve önemli bilgiler özet şeklinde bu materyale eklenmiştir.

- Sesli ve Görüntülü Eğitim Videosu: İlgili konular bilgisayarda anlatılarak, ekran görüntüsünün kaydedilmesiyle oluşan sesli ve görüntülü kaynaklardır. Bu kaynağın avantajı kodlamaların uygulamalı olarak gösterilmesi, öğrencinin dilediği yerde videoyu durdurabilmesi, kendi öğrenme hızına göre süreci ayarlayabilmesidir.

- Örnek Sorular ve Cevapları: Her konu sonunda öğrencilere sunulan örnek sorular her hafta için 5 sorudan oluşmaktadır. Bu kaynaklar 5 hafta boyunca yayımlanmıştır. Cevapların yer aldığı belge ise sorulardan ayrıdır 
ve soruların yayımlanmasından 2 - 3 gün sonra yayımlanmıştır. Bu kaynak sayesinde öğrencilerin örnek sorulardaki cevaplarını kontrol etmeleri ve doğru cevapları görmeleri amaçlanmıştır.

\section{Verilerin Analizi}

Akademik Güdülenme Ölçeğinden elde edilen veriler SPSS 22 programına girilmiş ve bu veriler üzerinden analizler yapılmıştır. İstatistiksel bilgilerin görülmesi, gruplar hakkında belli yargılara varılması amacıyla veriler üzerinde betimsel istatistik hesapları yapılmıştır. Betimsel istatistiklerde Ortalama (X), Standart Sapma (SS), Ortanca (Ortn), Tepe Değeri (TD), Çarpıklık Katsayısı (ÇK), Basıklık Katsayısı (BK) gibi bilgilere yer verilmiştir.

İlgili dersin harmanlanmış öğrenme yöntemi ile işlenmesinin öğrencilerin akademik güdülenmelerine etkisi olup olmadığını tespit etmek amacıyla grupların ön testleri ve son testleri karşılaştırılmıştır. Grupların puanlarını karşılaştırmak için analiz yapılmadan önce verilerin parametrik testlere uygunluğu incelenmiştir. Bu amaçla aşağıdaki varsayımlar test edilmiş ve bu varsayımların karşılandığı anlaşılarak parametrik testler uygulanmıştır. Can (2003)'a göre parametrik testlerin uygulanabilmesi için aşağıdaki varsayımların karşılanması gerekmektedir.

- Son test ve ön testlerden elde edilen puanlar gruplara göre normal dağılım göstermelidir: Bu varsayım için betimsel istatistikler incelenmiştir.

- Grupların varyansları homojen olmalıdır: Bu varsayım için ise Levene's Test puanının anlamlılık düzeyi incelenmiştir.

Yukarıdaki varsayımların karşılandığı anlaşılan veriler üzerinde parametrik testler uygulanmıştır.

Akademik güdülenme puanları bakımından ilk olarak grupların ön testleri karşılaştırılmıştır. Ön testler bakımından homojen olduğu anlaşılan grupların akademik güdülenme son test puanları karşılaştırılmıştır. Grupların ön testlerinin ve son testlerinin karşılaştırılmasında Bağımsız Gruplar t Testi kullanılmıştır. Ayrıca her bir grubun kendi içerisinde değişimleri tespit etmek için de İlişkili Örneklemler t Testi uygulanmıştır.

\section{Bulgular}

Grupların ön test puanları karşılaştırılmadan önce ön test puanlarının gruplara göre puanlamalarından elde edilen verilerin parametrik testlere uygunluğu tespit edilmeye çalışılmıştır. Bu amaçla verilerin normal dağılım göstermesi ve varyansların homojenliği varsayımları incelenmiştir. 
Tablo 1. Grupların Akademik Güdülenme Ön Test Betimsel İstatistik Sonuçları

\begin{tabular}{lccccccc}
\hline Grup Ad 1 & N & $\overline{\mathrm{X}}$ & Ortn & TD & SS & ÇK & BK \\
\hline Deney & 20 & 64.40 & 65.50 & 54 & 7.27 & -0.38 & -0.33 \\
Kontrol & 22 & 65.32 & 65 & 65 & 8.47 & -0.10 & 0.13 \\
\hline
\end{tabular}

Her iki grubunda merkezi eğilim ölçüleri olan ortalama, ortanca ve tepe değeri sonuçlarına göre her grup kendi içinde değerlendirildiğinde değerler arasında çok büyük farklar bulunmamaktadır $\left(\overline{\mathrm{X}}_{\text {deney }}=64.40\right.$ $\mathrm{TD}_{\text {deney }}=54-$ Ortndeney $_{\text {d }}=65.50, \overline{\mathrm{X}}_{\mathrm{kontrol}}=65.32-\mathrm{TD}_{\mathrm{kontrol}}=65-$ Ortnkontrol=65). Grupların çarpıklık ve basıklık katsayısı değerlerinin de \pm 1 aralığında olduğu görülmektedir. Buna göre verilerin akademik güdülenme ön test puanları dağılımının homojen olduğu söylenebilir. Ayrıca Levene's Test sonucunda elde edilen $\mathrm{p}$ değeri 0.69 olarak hesaplanmıştır. Bu sonuç varyansların eşit kabul edilebileceğini göstermektedir $(p>0.05)$.

Ön test puanlarının dağılımının homojen olması ve varyansların eşit kabul edilmesi verilerin parametrik testlere uygun olduğunu göstermektedir. Grupların akademik güdülenme ön test puanları arasında anlamlı fark olup olmadığını tespit etmek amaciyla grupların akademik güdülenme ön test puanları arasında Bağımsız Gruplar t Testi yapılmıştır.

Tablo 2. Grupların Akademik Güdülenme Ön Testlerinin Karşılaştırılması

\begin{tabular}{lccccc}
\hline Grup Ad 1 & $\mathrm{~N}$ & $\overline{\mathrm{X}}$ & $\mathrm{SS}$ & $\mathrm{t}$ & $\mathrm{p}$ \\
\hline Deney & 20 & 64.40 & 7.27 & -0.37 & $0.71^{*}$ \\
Kontrol & 22 & 65.32 & 8.47 & & \\
${ }^{*} \mathrm{p}>0.05$ & & & & &
\end{tabular}

Bağımsız Gruplar t Testi sonucuna göre gruplar arasında çalışma öncesinde akademik güdülenme bakımından anlamlı fark bulunmamaktadır $(\mathrm{p}=0.71>0.05)$. Gerçekleştirilen Bağımsız Gruplar $\mathrm{t}$ Testi sonucuna göre çalışma öncesinde grupların akademik güdülenme düzeyi bakımından homojen olduğu söylenebilir.

Tablo 3. Grupların Akademik Güdülenme Son Test Betimsel İstatistik Sonuçları

\begin{tabular}{lccccccc}
\hline Grup Ad1 & $\mathrm{N}$ & $\overline{\mathrm{X}}$ & Ortn & TD & SS & ÇK & BK \\
\hline Deney & 20 & 74.15 & 75.50 & 66 & 8.18 & -0.26 & -0.92 \\
Kontrol & 22 & 71.36 & 70 & 66 & 6.64 & -0.07 & -0.50 \\
\hline
\end{tabular}


Deney ve kontrol grubunda merkezi eğilim ölçüleri olan ortalama, ortanca ve tepe değeri sonuçlarına göre her grup kendi içinde değerlendirildiğinde değerlerin bir birine yakın olduğu görülmektedir $\left(\overline{\mathrm{X}}_{\text {deney }}=74.15-\mathrm{TD}_{\text {deney }}=66-\right.$ Ortndeney $_{\text {d }}=75.50, \overline{\mathrm{X}}_{\text {kontrol }}=71.36-\mathrm{TD}_{\text {kontrol }}=66-$ Ortnkontrol=70). Grupların çarpıklık ve basıklık katsayısı değerlerinin de \pm 1 aralığında olduğu görülmektedir. Buna göre verilerin akademik başarı ön test puanları dağılımının homojen olduğu söylenebilir. Ayrıca Levene's Test sonucunda elde edilen $\mathrm{p}$ değeri 0.17 olarak hesaplanmıştır. Bu sonuç varyansların eşit kabul edilebileceğini göstermektedir ( $p>0.05)$.

Son test puanlarının dağılımının homojen olması ve varyansların eşit kabul edilmesi verilerin parametrik testlere uygun olduğunu göstermektedir. Grupların akademik güdülenme son test puanları arasında anlamlı fark olup olmadığını tespit etmek amacıyla grupların akademik güdülenme son test puanları arasında Bağımsız Gruplar t Testi yapılmıştır.

Tablo 4. Grupların Akademik Güdülenme Son Testlerinin Karşılaştırılması

\begin{tabular}{lccccc}
\hline Grup Ad 1 & $\mathrm{~N}$ & $\overline{\mathrm{X}}$ & $\mathrm{SS}$ & $\mathrm{t}$ & $\mathrm{p}$ \\
\hline Deney & 20 & 74.15 & 8.18 & \multirow{2}{*}{1.21} & $0.17^{*}$ \\
Kontrol & 22 & 71.36 & 6.64 & & \\
*p $>0.05$ & & & & &
\end{tabular}

Bağımsız Gruplar $t$ Testi sonucuna göre çalışma sonrasında grupların akademik güdülenme düzeyleri ortalamaları arasında deney grubu lehine anlamlı fark bulunmamaktadır $(\mathrm{p}=0.17>0.05)$. Her ne kadar son test puan ortalamaları arasında deney grubu lehine fark olduğu görülse de $\left(\overline{\mathrm{X}}_{\text {deney }}=74.15>\overline{\mathrm{X}}_{\text {kntrol }}=71.36\right.$ ) bu farkın anlamlı olmadığı anlaşılmaktadır.

\section{Çalışma Boyunca Grupların Değişimleri ve Başarı Grafikleri}

Çalışma boyunca uygulanan geleneksel eğitim ile harmanlanmış eğitimin grupların akademik güdülenmeleri üzerindeki değişimini incelemek amacıyla her grup için kendi içinde ayrı olarak akademik güdülenme ön test ve son test puanları karşılaştırılmıştır. Deney ve kontrol gruplarının ön test ve son test verileri ile parametrik testlere uygun olduğu sonucu daha önce yapılan analizde elde edilmişti (Bkz: Tablo 3 ve Tablo 4).

Geleneksel eğitimin kontrol grubu öğrencileri üzerinde akademik güdülenme bakımından her hangi bir değişime neden olup olmadığını tespit etmek için kontrol grubunun ön test puanı ile son test puanı arasında İlişkili Örneklemler t Testi yapılmıştır. 
Tablo 5. Kontrol Grubunun Akademik Güdülenme Ön Test-Son Test Puanlarının Karşılaştırılması

\begin{tabular}{cccccc}
\hline Test Ad1 & $\mathrm{N}$ & $\overline{\mathrm{X}}$ & SS & $\mathrm{t}$ & $\mathrm{p}$ \\
\hline Son Test- Ön Test & 22 & 6.04 & 11.25 & 2.52 & $0.02^{*}$ \\
${ }^{*} \mathrm{p}<0.05$ & & & & &
\end{tabular}

İlişkili Örneklemler $t$ Testi sonucuna göre Geleneksel Eğitim'in işlendiği kontrol grubu öğrencilerinin akademik güdülenme son test puanlarının ön test puanlarına göre anlamlı derecede yüksek olduğu görülmektedir $(\mathrm{p}=0.02<0.05)$. Buna göre geleneksel eğitimin öğrencilerin akademik güdülenmelerini arttırmada etkisi olduğu söylenebilir.

Harmanlanmış eğitimin kontrol grubu öğrencileri üzerinde akademik güdülenme bakımından her hangi bir değişime neden olup olmadığını tespit etmek için deney grubunun akademik güdülenme ön test puanı ile son test puanı arasında İlişkili Örneklemler t Testi yapılmıştır.

Tablo 6. Deney Grubunun Akademik Güdülenme Ön Test-Son Test Puanlarının Karşılaştırılması

\begin{tabular}{cccccc}
\hline Test Ad 1 & $\mathrm{~N}$ & $\overline{\mathrm{X}}$ & $\mathrm{SS}$ & $\mathrm{t}$ & $\mathrm{p}$ \\
\hline${ }^{*} \mathrm{p}<0.05$ & 20 & 9.75 & 10.24 & 4.25 & $0.00^{*}$ \\
\hline Son Test- Ön Test & & & & &
\end{tabular}

Harmanlanmış eğitimin işlendiği deney grubu öğrencilerinin akademik güdülenme son test puanlarının ön test puanlarına göre anlamlı derecede yüksek olduğu görülmektedir $(p=0.00<0.05)$. Buna göre harmanlanmış eğitimin öğrencilerin akademik güdülenmelerini arttırmada etkisi olduğu söylenebilir.

Deney ve Kontrol grupları birbirinden bağımsız olarak ön test ve son test ortalamaları bakımından incelenmiştir. Uygulama süresince grupların ilgili testlerden aldıkları puan ortalamaları ve ortalamaların değişimleri aşağıdaki grafikte gösterilmiştir. 


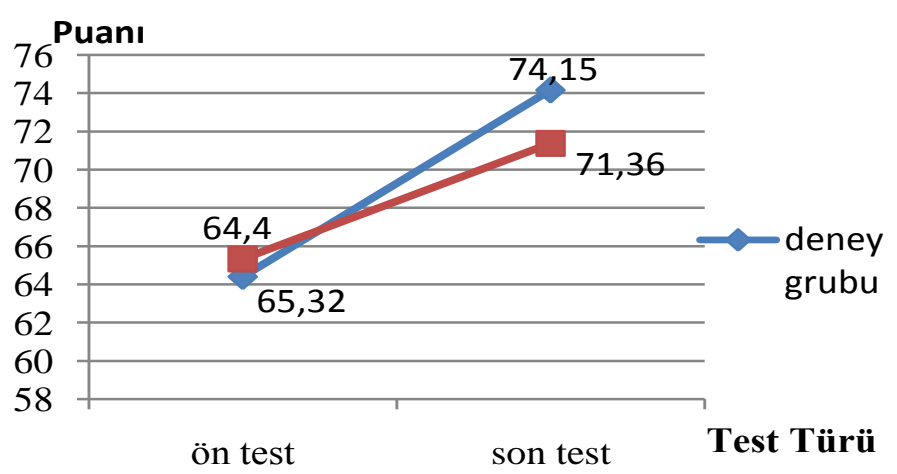

Grafik 1. Grupların akademik güdülenme ön test ve son test ortalamaları değişimleri

Grupların ön test puan ortalamalarının birbirine yakın olduğu $\left(\overline{\mathrm{X}}_{\text {deney }}\right.$ g. $=65.32, \overline{\mathrm{X}}_{\mathrm{kontrol} \mathrm{g.}}=64.4$ ), uygulama sonunda gerçekleştirilen son test puan ortalamalarının ise deney grubu lehine farklı olduğu $\left(\overline{\mathrm{X}}_{\text {deney g. }}=74.15, \overline{\mathrm{X}}_{\text {kontrol g. }}\right.$ = 71.36) görülmektedir.

\section{Tartışma, Sonuç ve Öneriler}

Elde edilen sonuçlara göre harmanlanmış öğrenmenin geleneksel öğrenmeye göre öğrencilerin akademik güdülenmelerini arttırmada etkisi bulunmamaktadır. Hem geleneksel öğrenmenin hem de harmanlanmış öğrenmenin öğrencilerin akademik güdülenme düzeylerini arttırmada etkili oldukları söylenebilir. Ancak her iki yöntem karşılaştırıldığında öğrencilerin akademik güdülenme düzeylerini değiştirmede yöntemlerin bir birine göre üstünlükleri bulunmamaktadır. Bu sonuca benzer şekilde Ünsal (2012) tarafından gerçekleştirilen geleneksel eğitim ile harmanlanmış öğrenmenin karşılaştırıldığı çalışmada harmanlanmış öğrenmenin güdülenmeyi arttırmada herhangi bir etkisi bulunmamıştır. Bunun aksine Korkmaz ve Aygün (2012) ile Sarıtepeci (2012), harmanlanmış öğrenme ortamının öğrencilerin başarılarını ve güdülenmelerini anlamlı derecede etkilediği sonucuna ulaşılmışlardır. Sucaromana (2013)'da Harmanlanmış Öğrenme ile öğrenim gören öğrencilerin geleneksel öğrenme ile öğrenim gören öğrencilere göre derse karşı güdülenme düzeyini önemli derecede yüksek bulmuştur. Topal (2013), Harmanlanmış Öğrenme ortamlarının öğrencilerin ilgi ve dikkatini çektiğinden dolayı güdülenmelerini arttırdığını fakat bu 
bireysel öğrenme ortamlarında öğrenci yalnızlık hissine kapılırsa güdülenme düzeyinin düş̧ebileceğini ifade etmektedir.

Literatürde, gerçekleştirilen çalışmalarda öğrencilerin özellikle bilgisayar ve internet teknolojilerini kullanmalarının akademik güdülenmeye etkileri de dikkat çekmektedir. Çoramık (2012) tarafından yapılan araştırma bulguları Bilgisayar Destekli Öğretim etkinliklerinin öğrencilerin akademik güdülenmelerine etkisi olmadığı yönündedir. Araştırmacıya göre bunun sebebi bilgisayarın dikkat dağınıklığına neden olmasıdır. Bu sonucun aksine Yıldız (2004), bilgisayarların dikkati daha canlı tuttuğunu ve güdülenmeyi arttırdığını ifade etmektedir. Özen ve Karaman (2001) ise internetin eğitim faaliyetlerinde kullanımının öğrencilerin akademik güdülenmelerini arttırdığını ifade etmiştir. Gürbüz ve Birgin (2008), geleneksel eğitimde öğrencilerin derse güdülenmelerinin tam anlamıyla gerçekleşmediğini ifade ederken, bilgisayar destekli materyallerin bunu kısmen sağladığı sonucuna ulaşmıştır. Bilgisayar ve internet teknolojilerinin eğitim amaçlı kullanımında bir birinden farklı sonuçlar elde edilmiştir. Bilgisayar ve internetin eğitim amaçlı kullanımı sürecinde öğrencilerin kendi oto kontrol sistemleri önemli bir yere sahiptir. Hemen her konuda başvuru kaynağı olan internet ve bilgisayarlar öğrenme sürecinde amacı dışında kullanılmaya oldukça müsaittir. Bu süreçte öğrencilerin kendilerini kontrol ederek bilgisayar ve interneti amaca yönelik kullanmaları derse karşı güdülenmelerini arttırabilir.

Harmanlanmış Öğrenme ile ilgili olarak Lim ve Morris (2009) tarafından gerçekleştirilen çalışmaya göre Uzaktan Eğitim deneyimine sahip öğrencilerin güdülenme ve öğrenme düzeyi, uzaktan eğitim almayan öğrencilere göre anlamlı düzeyde düşük iken Balaman (2015) tarafından gerçekleştirilen çalışmaya göre Web Tabanlı Uzaktan Eğitim ortamları öğrencilerin güdülenme düzeylerini arttırmaktadır.

Sınıf ortamı dışında, bilgisayar ve internetin eğitim amaçlı kullanımı yoluyla gerçekleştirilen uzaktan eğitim çalışmaları kapsam bakımından oldukça geniştir. Uzaktan eğitim ortamlarının sağlanmasında kullanılan teknolojiler, araç gereçler, öğretim tasarımları gibi birçok parametre bulunmaktadır. Bu parametreler öğrencilerin derse karşı güdülenmelerini etkilemektedir. $\mathrm{Bu}$ nedenle çalışmalarda öğrencilerin derse karşı güdülenmeleri ile ilgili olarak farklı sonuçlar elde edildiği görülmektedir.

Çalışmada Web Tabanlı Eğitimi gerçekleştirmek için sadece eş zamansız eğitim yapılmıştır. Buna ilaveten web konferans veya video konferans gibi yollarla eş zamanlı eğitim de yapılarak akademik güdülenmeye etkisi incelenebilir. Eş zamanlı eğitimler öğrenciler için öğretimde alışılagelmişin dışında bir yöntem olarak ilgi çekici olabilir. 
Öğrencilerin ilgisini çeken bu yöntem güdülenmenin artmasında etkili olabilir.

Çalışmada Öğretim Yönetim Sistemi kullanılmamıştır. Öğretim Yönetim Sistemi internet üzerinden gerçekleşen uzaktan eğitim türlerinde birçok avantaj sağlamaktadır. Bu avantajlar arasında sistemin kullanımının raporlanması, öğrenciyi yönlendirerek ve farklı öğretim etkinlikleri sunarak kullanım kolaylığı sağlaması, forum, mesaj gönderme, sohbet gibi etkileşimli ortamlar sağlama sayılabilir.

Web sayfasında konu anlatım materyali, sesli ve görüntülü ders videosu, soru ve cevaplar gibi materyaller kullanılmıştır. Bu materyaller oyunlar, etkinlikler v.b. farklı türden materyallerle zenginleştirilerek öğrencilere sunulabilir.

Veritabanı Yönetim Sistemleri dersi kapsamında yürütülen bu çalışma dışında farklı dersler kapsamında da Harmanlanmış Öğrenmenin öğrencilerin akademik güdülenme düzeylerine etkisi araştırılabilir. Özellikle fen bilimleri gibi zengin ve görsel 2 boyutlu, 3 boyutlu materyallerin hazırlanmasına uygun derslere ait konuların tercih edilmesi öğrencilerin daha fazla güdülenmelerini sağlayabilir. Çünkü gerçeğe yakın hazırlanmış materyaller öğrenmeyi ve güdülenmeyi olumlu yönde etkileyebilir.

\section{Kaynakça}

Akbay, S. E. (2009). Cinsiyete Göre Üniversite Öğrencilerinde Akademik Erteleme Davranışı: Akademik Güdülenme, Akademik Özyeterlik ve Akademik Yükleme Stillerinin Rolü. Yüksek Lisans Tezi, Mersin Üniversitesi, Mersin.

Aktaş, M. (2013). Fen ve Teknoloji Dersinde Web Tabanlı Uzaktan Eğitimin Öğrencilerin Akademik Başarı ve Tutumları Üzerindeki Etkisi. Yüksek Lisans Tezi, Bülent Ecevit Üniversitesi, Zonguldak.

Aydın, F. (2010). Akademik Başarının Yordayıcısı Olarak Akademik Güdülenme, Öz Yeterlilik ve Sinav Kaygısı. Yüksek Lisans Tezi, Hacettepe Üniversitesi, Ankara.

Balaman, F. (2015). Web Tabanl Uzaktan Eğitimin Meslek Yüksekokulu Öğrencilerinin İnternet Progracılığı 2 Dersindeki Akadmeik Başarılarına Etkisi. Doktora Tezi, Dicle Üniversitesi, Diyarbakır.

Bonk, C., \& Graham, C. (2006). The Handbook of Blended Learning, Global Perspectives, Local Designs. San Francisco: Pfeiffer Publishing.

Bozanoğlu, İ. (2004). Akademik Güdülenme Ölçeği: Geliştirmesi, Geçerliği, Güvenirliği. Ankara Üniversitesi Ĕ̆itim Bilimleri Fakültesi Dergisi, 37(2), 83-98. 
Büyüköztürk, Ş., Kılıç Çakmak, E., Karadeniz, Ş., Akgün, Ö. E., \& Demirel, F. (2014). Bilimsel Araştırma Yöntemleri. Ankara: Pegem Akademi.

Can, A. (2013). SPSS ile Bilimsel Araştırma Sürecinde Nicel Veri Analizi. Ankara: Pegem Yayıncilık.

Çardak, Ç. S. (2013). Harmanlanmış Öğrenme Sürecinde Öğrencilerin Etkileşimlerinin ve Öğrenme Düzeylerinin İncelenmesi. Doktora Tezi, Anadolu Üniversitesi, Eskişehir.

Çepni, S. (2012). Araştırma ve Proje Çalışmalarına Giriş. Trabzon: Süzer Kitap Kirtasiye.

Çoramık, M. (2012). Manyetizma Ünitesinin Bilgisayar ve Deney Destekli Etkinlikler ile Öğretiminin 11. Sinıf Öğrencilerinin Özyeterlilik ve Üstbilişlerine, Tutumlarına, Güdülenmelerine ve Kavramsal Anlamalarına Etkisi. Yüksek Lisans Tezi, Balıkesir Üniversitesi, Balıkesir.

Dağ, F. (2011). Harmanlanmış (Karma) Öğrenme Ortamları ve Tasarımına İlişkin Öneriler. Ahi Evran Üniversitesi Ĕ̆itim Fakültesi Dergisi, 12(2), 73-97.

Demir, Z. (2008). Uzaktan Ĕ̆itim Öğrencilerinin Akademik Güdülenme Düzeyleri (SAU Örneği). Yüksek Lisans Tezi, Sakarya Üniversitesi, Sakarya.

Dennis, A., Cakir, H., Korkmaz, A., Duffy, T., Bichelmeyer, B., \& Bunnag, J. (2006). Student Achievement in a Blended-Learning Environment: Lessons From the Cisco Networking Academy. 04 22, 2015 tarihinde "http://www.indiana.edu/ iuteam/webdesign/conference_papers/A ERA06_submission_paper.pdf" adresinden alınd1.

Dikmenli, Y., \& Ünaldı, Ü. E. (2013). Harmanlanmış Öğrenme ve Sanal Sınıfa Dönük Öğrenci Görüşleri. Amasya Üniversitesi Eğitim Fakültesi Dergisi, 2(2), 326-347.

Ezginci, Y. (2008). Biyomedikal Mühendisliğine Giriş Dersinin İnternet Üzerinde Tasarımı. Doktora Tezi, Selçuk Üniversitesi, Fen Bilimleri Enstitüsü, Konya.

Garisson, R., \& Vaughan, N. (2008). Blended Learning in Higher Education. San Francisco: Jossey Bass.

Geçer, A. (2013). Harmanlanmış Öğrenme Ortamlarında Öğretim ElemanıÖğrenci İletişimi. Kuram ve Uygulamada Ĕ̆itim Bilimleri, 13(1), 349367.

Geçer, A., \& Dağ, F. (2012). Bir Harmanlanmış Öğrenme Tecrübesi. Kuram ve Uygulamada Ĕ̆itim Bilimleri, 12(1), 425-442.

Ginns, P., \& Ellis, R. (2007). Quality in Blended Learning: Exploring The Relationships Between On-Line and Face-to-Face Teaching and Learning. The Internet and Higher Education, 10(1), 53-64. 
Gürbüz, R., \& Birgin, O. (2008). Bilgisayar Destekli Öğretime İlişkin Öğretmen Ve Öğrenci Görüşleri . II. Uluslararası Bilgisayar Ve Öğretim Teknolojileri Sempozyumu, 199-205, İzmir.

Karasar, N. (2007). Bilimsel Araştırma Yöntemi. Ankara: Nobel Yayıncılık.

Korkmaz, Ö., \& Aygün, M. (2012). Impact of Blended Learning Environments Based on Algo-Heuristic Theory on Some Variables. Mevlana International Journal of Education (MIJE), 2(2), 25-38.

Lim, D. H., \& Morris, M. L. (2009). Learner and Instructional Factors Influencing Learning Outcomes within a Blended Learning Environment. Educational Technology E Society, 12(4), 282-293.

Moore, M. G. (Ed.) (2013). Handbook of Distance Education. New York: Routledge Publishing.

Naaj, M. A., Nachouki, M., \& Ankit, A. (2012). Evaluating Student Satisfaction with Blended Learning in a Gender-Segregated Environment. Journal of Information Technology Education: Research, (11), 186-200.

Oral, B. (Ed.) (2011). Öğrenme Öğretme Kuram ve Yaklaşımları. Ankara: Pegem Yayınları.

Özen, Ü., \& Karaman, S. (2001). Web Tabanlı Uzaktan Eğitimde Sistem Tasarımı. Akdeniz İ.I.B.F. Dergisi, 81-102.

Pérez, M. V., López, M., \& Ariza, L. (2011). Blended Learning in Higher Education: Students' Perceptions And Their Relation to Outcomes. Computers \& Education, 56(3), 818-826.

Picciano, A., \& Dziuban, C. (Ed.) (2007). Blended Learning Research Perspectives. Sload Publishing.

Schober, A., \& Keller, L. (2012). Impact Factors for Learner Motivation in Blended Learning Environments. IJET, 7(2), 37-41.

Sönmez, V. (2010). Program Geliştirmede Öğretmen El Kitabı. Ankara: Pegem Yayınları.

Sucaromana, U. (2013). The Effects of Blended Learning on the Intrinsic Motivation of Thai EFL Students. Canadian Center of Science and Education, 6(5), 141-147.

Topal, A. D. (2013). Tıp Fakültesi Öğrencileri İçin Harmanlanmış Öğrenme Ortamı İle Hazırlanan Anatomi Dersinin Öğrencilerin Güdülenmeleri ve Akademik Başarıları Üzerindeki Etkisinin İncelenmesi. Doktora Tezi, Gazi Üniversitesi, Ankara.

Uluyol, Ç., \& Karadeniz, Ş. (2009). Bir Harmanlanmış Öğrenme Ortamı Örneği: Öğrenci Başarısı Ve Görüşleri. Yüzüncü Yıl Üniversitesi, Eğitim Fakültesi Dergisi, 6(1), 60-84. 
Usta, E., \& Mahiroğlu, A. (2008). Harmanlanmış Öğrenme ve Çevrimiçi Öğrenme Ortamlarının Akademik Başarı ve Doyuma Etkisi. Ahi Evran Üniversitesi Kırşehir Eğitim Fakültesi Dergisi , 1-15.

Ünal, M. (2013). Lise Ögrencilerinin Akademik Güdülenme Düzeylerinin Bazı Degiskenler Açısından Yordanması. Yüksek Lisans Tezi, Dokuz Eylül Üniversitesi, İzmir.

Ünsal, H. (2012). Harmanlanmış Öğrenmenin Başarı ve Motivasyona Etkisi. Türk Eğitim Bilimleri Dergisi, 10(1), 1-27.

Yıldız, R. (Ed.) (2004). Öğretim Teknolojleri ve Materyal Geliştirme. Konya: Atlas Kitabevi. 